DOI: https://doi.org/10.34137/jilses.867019

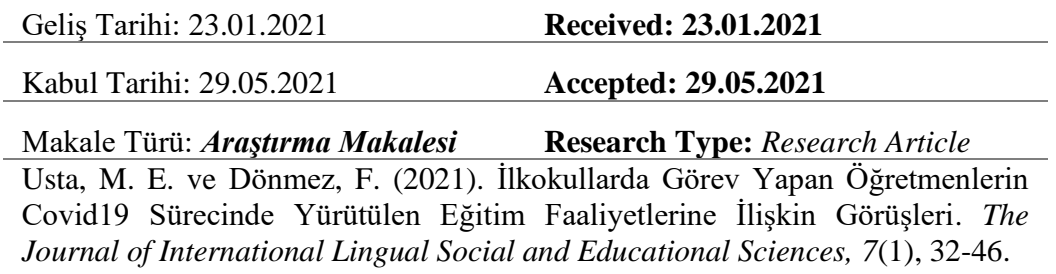

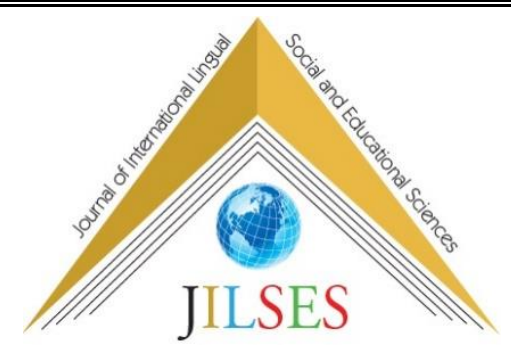

\title{
İlkokullarda Görev Yapan Öğretmenlerin Covid19 Sürecinde Yürütülen Eğitim Faaliyetlerine İlişkin Görüşleri*
}

\section{Mehmet Emin USTA ${ }^{1}$ Ferhat DÖNMEZ $^{2}$}

\section{$\ddot{\mathbf{O z}}$}

Covid19 salgını modern dünyanın yakın zamanda hiç yașamadı̆̆ı toplumsal bir durumu ortaya çıkardl. Bu toplumsal durum yaşamın olağan akışını alt üst etti. Hiç alışkın olmadlğımız yeni bir toplumsal gerçeklik doğdu. Bu gerçeklik başta ticaret, insan ilişkileri, gündelik alışkanlıklar, ulaşım ve eğitim dahil birçok alanı olağan akışında yapılamaz hale getirdi. Sayılan bu sektörler içinde belki de en çok etkileneni eğitim alanı oldu. Eğitim kurumları bir anda kapandı ve bu yeni durum karşısında çaresiz kaldl. Kısa süreli bu çaresizlikten sonra neredeyse tüm dünyada uzaktan eğitime geçilerek, uzaktan eğitim imkânı sağlayan site, program ve portallar bir anda eğitim yasantısının odağına yerlestiler. Ancak yönetici, öğretmen ve öğrencilerin bu sürece yeterince hazır olmadıklarl görüldü. Bu çalışmada ilkokullarda görev yapan ögrretmenlerin Covid19 sürecinde yürütülen eğitim faaliyetlerine ilişskin görüşleri yarı yapılandırılmış bir görüșme formuyla öğrenilmeye çallşsllmıștır. Nitel yöntemle veri elde etmek amacıyla 20 öğretmenden oluşan bir çalıșma grubu olușturulmus, çalıșma grubuna seçilen öğretmenlerin kent merkezi ve köyde çalışıyor olmalarına dikkat edilmiştir. Çalışma sonucunda İlkokullarda Görev Yapan Öğretmenlerin Covid19 Sürecinde Yürü̈tülen Eğitim Faalivetlerine ilișkin olarak bașlangıçta ciddi sorunlarla karșllaștığl, öğretmenlerin ve öğrencilerin bu konuda yeterince eğitimli ve deneyimli olmadı̆̆l, ögrencilerin internet ve ekipman konusunda yeterince imkana sahip olmadiğl, Milli Ĕgitim Bakanlı̆̆g 'nın yeterli olanaklarının olmadığ ayrıca uzaktan eğitimin yüz yüze eğitim kadar etkili olmadı̆g sonucuna ulaşllmıștır. Bununla birlikte ilerleyen süreçte Bakanlı, öğrenci, ögretmen ve velilerin tecrübe edindiği ifade edilmiștir. Ögrrencilere internet ve bilgisayar desteği verilmesi, EBA portalının içerik itibariyle zenginleştirilmesi, ögretmenlerin uzaktan eğitim ile ilgili olarak eğitilmesi ve yüz yüze eğitimin belli bir planlamayla mutlaka başlatılması gibi öneriler getirilmiştir.

Anahtar Kelimeler: Covid19, Eğitim, Öğretmen, Pandemi, Uzaktan eğitim

Opinions of Teachers Working in Primary Schools Regarding Educational Activities Conducted During Covid19

\section{Abstract}

The Covid19 pandemic has revealed a social situation that the modern world has never experienced recently. This social situation upset the usual flow of life. A new social reality has emerged that you are not used to. This reality made many fields, including commerce, human relations, daily habits, transportation and education, unfeasible in their usual flow. Among these sectors, education was perhaps the most affected. Educational institutions suddenly closed and were helpless against the new situation. After this short-term helplessness, almost all over the world, distance education has been switched to, and sites, programs and portals that provide distance education have suddenly become the focus of educational life. However, it was observed that administrators, teachers and students were not prepared enough for this process. In this study, it was tried to learn the opinions of teachers working in primary schools on the educational activities carried out during the Covid19 process through a semistructured interview form. In order to obtain data with qualitative method, a study group consisting of 20 teachers was formed, and attention was paid to the fact that the teachers selected for the study group were working in the city center and village. As a result of the study, the teachers working in primary schools faced serious problems in the beginning regarding the Educational Activities carried out in the Covid19 Process, teachers and students were not sufficiently educated and experienced in this regard, students did not have enough opportunities in internet and equipment, the Ministry of National Education did not have sufficient opportunities. it was concluded that the training is not as effective as face-to-face training. However, it was stated that the Ministry, students, teachers and parents gained experience in the following process. Suggestions were made such as providing internet and computer support to students, enriching the EBA portal in terms of content, educating teachers about distance education and starting face-to-face education with a certain planning.

Keywords: Covid19, Education, Teacher, Pandemic, Distance education

\footnotetext{
* Bu makale Harran Üniversitesi Sosyal Bilimler Enstitüsü Eğitim Yönetimi ABD’nda hazırlanmış aynı adlı yüksek lisans projesinden üretilmiştir.

${ }^{1}$ Doç. Dr., Harran Üniversitesi, mehmeteminusta3@gmail.com, https://orcid.org/0000-0003-2355-1203

2 Öğretmen, Şanlıurfa Milli Eğitim Müdürlüğü, ferhatnadide2015@gmail.com, https://orcid.org/0000-0002-4025-4254
} 


\section{Giriş}

Pandemi, bütün dünyayı etkisi altına alan salgın hastalık olarak tanımlanmaktadır. Salgın hastalıkların sağlık üzerindeki etkileri ön planda bulunmakta olup, psikolojik etkilerinin ikinci plana atıldığı görülmektedir. Salgın hastalıkların bedensel olarak etkileri ciddi sonuçlar gösteriyor olsa da insanlar üzerindeki psikolojik etkileri uzun yıllar izler bırakmaktadır (Taylor, 2019). Salgın hastalık sürecinde insanlar üzerindeki en yaygın duygunun, bireyin hem kendi sağlığına hem de yakınlarının sağlığına ilişkin duymuş olduğu kaygı olduğu görülmektedir.

T.C. Sağlık Bakanlığı Merkez ve Taşra Teşkilatlarının salgın sürecinde üzerlerine düşen görevler, kısmi zamanlarda güncellenen Covid19 Rehberleri ya da kurum içi yazışmalar vasıtasıyla yapılabilmektedir. Bu rehber, ikinci ve üçüncü basamak sağlık kuruluşlarında alınması gereken tedbirleri, tedavi yöntemlerini ve uygulanacak protokolleri ihtiva etmektedir. Sağlık Bakanlığı, pandemi sürecini 2 ayrı başlık altında topladığı örgütlenmeler ile sürdürmektedir (www.ttb.gov.tr, Erişim tarihi: 12.06.2020).

Covid19 sürecinde en çok duyulan ifadelerden biri de "sosyal mesafe" kavramıdır. "Sosyal mesafe" uygulamasının temel amacı salgını ortadan kaldırmak değildir. Bu süreçte sosyal mesafenin asıl amacı salgının yayılma hızını yavaşlatmak ve süreci yönetmek için gerekli olan zamanı kazandırmaktır. Özellikle Covid19 salgınını kontrol altına alabilecek bir aşı bulununcaya kadar, sağlık sistemi altyapısının çökmesinin önüne geçmek için bulunmuş bir tedbirdir (Özatay ve Sak, 2020a; Özatay ve Sak, 2020b)

Salgın nedeniyle, sosyal mesafeyi sağlamak amacıyla okullarda yüz yüze eğitime ara verilmiş, boş zamanlar için kullanılan alanların faaliyetleri durdurulmuş, kamu ve özel sektörde çalışanlara esnek ve uzaktan çalışma imkânları sunulmuştur. 65 yaş ve üzerindekiler ile 20 yaşın altındaki bireylere sokağa çıkma yasağı getirilmiştir. Bunun yanında, tüm yaş gruplarına hafta sonları ve resmi tatillerde sokağa çıkma yasağı uygulanmıştır. Şehirler arası seyahat kısıtlaması getirilmiştir (Öztürk, Yılmaz, Demir Erbil ve Hazer, 2020).

\section{Covid19 Pandemisinin Eğitim Öğretim Faaliyetlerindeki Etkisi}

Kriz dönemlerinde uzun vadeli planlamalar yapmak ve bu planları yaşama geçirmek güç bir iştir. 2020 y1lına girişin hemen akabinde tüm dünyada meydana gelen Covid19 salgını da bu kriz alanlarından biridir. Covid19 salgını nedeniyle 2019-2020 eğitim-öğretim yılı başında neredeyse tüm dünyada eğitim kurumları kapatılmış ve değişik düzeylerde sosyal hayatı kısıtlama uygulamalarına gidilmiştir (Daniel, 2020; aktr. Sarı ve Nayır, 2020). $\mathrm{Bu}$ çerçevede neredeyse her ülkede belli düzeylerde okullar ve diğer eğitim kurumları uzaktan eğitim uygulamalarına yönelmişlerdir. Bu yönelimler kriz yönetiminin bir parçası olarak cereyan ettiği için öğretmenlerin ezici çoğunluğu, yeterince tecrübeye sahip olmadığı halde, kendini uzaktan eğitim uygulamalarının içinde bulmuştur (Karip, 2020). Artık hiçbir şeyin eskisi gibi olamayacağı düşüncesi ile öğretmenlerin çoğu daha önce uzaktan eğitim araçlarını hiç kullanmadığı halde bunları öğrenme yoluna gitmiştir (Çetinkaya Aydın, 2020).

Öğretmenlerin uzaktan eğitim ve uzaktan eğitim materyali hazırlama açısından bilgi ve becerilerinin yeterince gelişmediği hesaba katıldığında, yapılan uzaktan eğitim çalışmalarının kusursuz olduğunu iddia etmek mümkün görünmemektedir. Ayrıca uzaktan eğitim teorik geçmişi olan bir bilim alanıdır ve başarılı bir uzaktan eğitim uygulaması için hem planlama yapılmalı hem de uzaktan eğitime katılacak tüm öğretmenlerin eğitilmesi zorunludur (Shattuck, Dubins ve Zilberman, 2011).

Başta uzaktan eğitim araçlarını kullanmada zorluk çeken öğretmenler, uygulamalı eğitimler sayesinde uzaktan eğitim araçlarının kullanımına kolayca adapte olabilirler. Eğitim kurumlarının uzaktan eğitim sürecinin planlamasında yaptıkları bazı hatalar (öğrenme yönetim sistemi ve canlı ders modülleri tercihi gibi) öğretmenlerin zorlanmasına ve enerjilerinin boşa gitmesine neden olabilir. Türkiye'de üniversiteler uzaktan eğitim konusunda en tecrübeli eğitim kurumlarıdır. Üniversiteler, Yükseköğretim Kurulu’na (YÖK) bağlıdır. YÖK, salgın sürecinin neredeyse başında üniversitelere derslerin uzaktan eğitim yöntemi ile verilmesi yönünde emir vermiş ve 20192020 eğitim-öğretim yılı ilkbaharında herhangi bir yüz yüze eğitim yapılmayacağını ifade etmiştir. Üniversiteler, imkanları ölçüsünde "senkron", "asenkron" veya "hem senkron hem de asenkron" olarak uzaktan eğitim faaliyetlerini yürütmüşlerdir. Bazı altyapısı yetersiz yükseköğretim kurumlarının donanım ve yazılım açısından ciddi harcamalar yaptıkları da görülmüştür. Bu ciddi bir maliyet artışı anlamına gelmektedir (Durak, Çankaya ve İzmirli, 2020, 791).

\subsection{Uzaktan Eğitim}

Tüm dünyada Türkiye'de yaşanan sorunlara benzer sorunlarla karşılaşılmıştır. Dünyada uzaktan eğitim sisteminin geçmişi yaklaşık olarak üç yüz yıl öncesine kadar uzanmaktadır. Türkiye'de uzaktan eğitim konusu ise biraz gecikmeli olarak gündeme gelmiştir. Türkiye'de 1923 ile 1960’lı yıllar arasında uzaktan eğitim konusu sadece kavramsal düzeyde tartışılmıştır. 1970'li yıllardan sonra birkaç basit girişimle sınırlı da olsa ortaöğretim düzeyinde bazı adımlar atılmıştır. Anadolu Üniversitesi Açıköğretim Fakültesi’nin 1980 sonrası kurulmasılyla birlikte uzaktan 
eğitim yükseköğretimde daha çok bilinir olmuştur (Durak, Çankaya ve İzmirli, 2020; Bozkurt, 2017, 86). 2000'li yıllardan sonra başta internet teknolojisi ve dijital alan olmak üzere uzaktan eğitim alanı tam bir işlev kazanmıştır. Yurtiçi ve yurt dışı eğitim olmak üzere milyonlarca kişiye eğitim fırsatları sunulmuştur (Gürer, Tekinarsan ve Yavuzalp, 2016, 52).

\subsubsection{Uzaktan Eğitimin Özellikleri}

Uzaktan eğitim değişik açılardan yüz yüz yüze eğitimden farklılaşmaktadır. Bunlardan bazıları şunlardır:

-Uzaktan eğitim yöntemiyle yürütülen dersler, senkron (eş zamanlı) veya asenkron (eş zamansız) biçiminde verilebilmektedir (Durak, Çankaya ve İzmirli, 2020).

-Dersler kayıt altına alınabilmektedir.

-Öğrenci dilediği zaman derslerini kayıtlardan izleyebilmektedir.

-Öğrenme günün her anına yayılabilmektedir.

$\mathrm{Bu}$ özellikler bazen avantaj bazen de dezavantaj olarak görülebilmektedir. Bu nedenle uzaktan eğitim uygulamalarının avantaj ve dezavantajlarına aşağıda yer verilmiştir.

\subsubsection{Uzaktan Eğitimin Avantajları}

Uzaktan eğitim bir anda çok fazla öğrenciye ulaşma imkânı sunmakta, bir defa kullanılan alt yapı onlarca ve hatta binlerce defa kullanılabilmekte, eğitimcinin öğrencinin o anki bedensel ya da kişisel durumuna takılmasını engellemekte, öğrenci dersi dinlerken yemek ve içmek gibi kimi ihtiyaçlarını gidererek rahat bir ortam sağlayabilmektedir. Ayrıca kayıt sistemi sayesinde ders içeriği ve öğretmen sunuşu yıllarca korunarak güçlü bir ders arşivi oluşturulabilmektedir.

\subsubsection{Uzaktan Eğitimin Dezavantajları}

Covid19 salgın döneminde eğitimde yaşanan olumsuzluklar arasında sayılabilecek durumlar değerlendirildiğinde, önde gelen sorunların öğrenme kaybı, okulu bırakma oranlarının artması ve beslenme olarak ortaya çıktığı görülmektedir (Saavedra, 2020, aktr. Sarı ve Nayır, 2020). Ayrıca çevrimiçi verilen eğitimlere erişmede imkânı yetersiz olan öğrencilerin varlığı (Saran, 2020, aktr. Sarı ve Nayır, 2020) özellikle gelişmekte olan ülkelerde ortaya çıkan önemli bir sorundur. Uzaktan eğitim sürecinde öğretmenin kameralar üzerinden öğrenciyi her zaman göremeyişi ve sesini duyamayışı, öğrencinin öğretmeni izliyor görünüyorken başka işlerle meşgul olabilmesi, öğretmenin güçlü bir göz teması sağlayamaması vb. olumsuzlukların da sayılması mümkündür. Bununla beraber doğrudan eğitim faaliyetleri ile ilgili olmayan bazı hususların da uzaktan eğitim faaliyetlerini olumsuz etkilediği gözlenmiştir.

\subsection{Covid19 Pandemi Sürecinde Türkiye'de Uygulanan Uzaktan Eğitim}

Artan vaka sayısı sonrası tüm eğitim kademesindeki süreçler önce üç hafta ertelenmiş daha sonra ise süreçlerin 2019-2020 Güz dönemi sonuna kadar uzaktan eğitim yöntemiyle devam ettirilmesine karar verilmiştir. Böylece Türkiye'de aynı anda milyonlarca öğrenciye daha önceden uzaktan eğitim deneyimleri olmamasına rağmen uzaktan eğitim ile dersler verilmiştir. Uzaktan eğitim, kısaca fiziksel bir ortama ihtiyaç duyulmadan farklı iletişim araçları üzerinden gerçekleştirilen eğitim modeli olarak ifade edilebilir. Uzaktan eğitim, günümüzde salgın ön planda olmak üzere, bazı kısıtlar nedeniyle eğitim teknolojilerinin kullanılmasına imkân tanıyan ve firsat eşitliğini ön planda tutan eğitim modelidir (Kaya, 2002).

Öğrencilerin yaşadıkları sorunların nedenleri arasında, uzaktan eğitimi geleneksel eğitime nazaran daha esnek algılamaları da ifade edilebilir. Çünkü bu sayede, varsa canlı derslere katılım zorunluluğu olmaksızın öğrenimlerini devam ettirebilecekleri algısı etkili olabilmektedir. Halbuki uzaktan eğitim ile beklenen çıktıların elde edilebilmesi için öğrencilerin sorumluluklarını yerine getirebilmeleri ve motivasyonlarının yüksek olması gerekmektedir $(\mathrm{Cab} 1,2016)$. Diğer bir ifade ile uzaktan eğitimdeki öğrencilerin de yüz yüze eğitimdeki öğrenciler gibi sorumlulukları bulunmaktadır. Bu sorumlulukların yerine getirilmemesi veya eksik olması ise uzaktan eğitimi olumsuz etkilemektedir. Üniversitelerdeki uzaktan eğitim süreçlerinde farklı uygulamalar denenmiştir. Bu uygulamalar genel olarak, (1) ders notlarının öğrencilerle paylaşılması, (2) derslerin dijital platformlar üzerinden canlı olarak işlenilmesi veya (3) öğretim elemanlarının çektiği ders videolarını paylaşması şeklinde gruplandırılabilir.

Bazı kurumlarda bu uygumalar karma olarak da uygulanmıştır. Bununla birlikte derslerin değerlendirilmesinde de dijital platformlar üzerinden farklı yöntemler kullanılmıştır. Bu yöntemler; (1) ödevlerin elektronik olarak alınması ve puanlanması, (2) projelerin modüller veya videolar biçiminde sistem üzerinden öğretmene gönderilerek ögretmen tarafından puanlanması, (3) online yazılı sınavlar ve (4) online sözlü sınavlar şeklinde ifade edilebilir. 
Türkiye'de yaklaşık iki yıl boyunca tüm öğretim kurumlarında uygulanan uzaktan eğitimin değerlendirilmesi sonraki süreçlerin planlanması için de önem arz etmektedir. Bu süreçlerin değerlendirilmesinde üniversite öğrencilerinin uzaktan eğitime yönelik görüşleri önemli bir veri kaynağı olarak ifade edilebilir. Bu çalışmanın amacı, salgın döneminde Türkiye'de uygulanan uzaktan eğitime yönelik olarak ilgililerin görüşlerinin değerlendirmesini yapmaktır. Ayrıca uzaktan eğitimin etkili olma durumuna dair bazı bulgulara ulaşılması hedeflenmektedir.

\section{Yöntem}

Araştırmanın bu bölümünde; araştırma modeli, çalışma grubu, veri toplama aracı, veri toplama süreci, verilerin çözümlenmesi ve bulgulara yer verilmiştir.

\subsection{Araştırmanın Modeli}

Nitel yöntemde gerçekleştirilen bu araştırmada olgubilim (fenomoloji) deseni kullanılmıştır. Olgubilim araştırmalar farkında olduğumuz ancak derinlemesine ve ayrıntılı bir anlayışa sahip olmadığımız olgulara odaklanır ve birkaç kişinin bir olgu ya da kavramla ilgili deneyimlerinin ortak anlamını tanımlar (Yıldırım ve Şimşek, 2011).

\section{2. Çalıșma Grubu}

Araştırmanın evrenini Şanlıurfa ilinde devlet ilkokullarında okullarında görev yapan öğretmenler oluşturmaktadır. Çalışma grubunu ise kolay ulaşılabilir örnekleme yöntemine dayalı olarak belirlenen 20 öğretmen oluşturmuştur. Çalışma grubunun özellikleri aşağıdaki tabloda verilmiştir.

Tablo 1: Çalışma grubunun demografik özellikleri

\begin{tabular}{|c|c|c|c|c|c|c|c|c|}
\hline $\begin{array}{l}\text { Kod } \\
\text { İsim }\end{array}$ & Cinsiyet & $\begin{array}{l}\text { Mezun } \\
\text { olduğunuz } \\
\text { Kurum }\end{array}$ & $\begin{array}{l}\text { Mezuniyet } \\
\text { Durumu }\end{array}$ & $\begin{array}{l}\text { Mesleki } \\
\text { Deneyim } \\
\text { (kıdem) }\end{array}$ & Yaşınız & $\begin{array}{l}\text { Üniversitede } \\
\text { uzaktan } \\
\text { eğitim içerikli } \\
\text { bir eğitim } \\
\text { aldınız mı? }\end{array}$ & $\begin{array}{l}\text { Günlük uzaktan eğitime } \\
\text { ayırdığınız zaman }\end{array}$ & $\begin{array}{l}\text { Sınıfinızdaki } \\
\text { öğrenci sayısı }\end{array}$ \\
\hline Kişi1 & Kadın & Eğitim Fak. & Lisans & $1-5$ Yil & $31-40$ & Hayır & $180 \mathrm{dk}$ (3 saat ve üzeri) & $31-45$ \\
\hline Kişi2 & Erkek & Eğitim Fak & Lisans & $6-10 Y_{11}$ & $20-30$ & Hayır & $31-60 \mathrm{dk}$ (1 saat) & 46 üzeri \\
\hline Kişi3 & Erkek & Eğitim Fak & Lisans & $1-5 Y_{1}$ & $20-30$ & Hayır & $61-120 \mathrm{dk}$ (2 saat) & $16-30$ \\
\hline Kişi4 & Erkek & Eğitim Fak & Lisans & $1-5$ Y1l & $20-30$ & Hayır & $31-60 \mathrm{dk}$ (1 saat) & $31-45$ \\
\hline Kiși5 & Kadın & Eğitim Fak & Lisans & $1-5 Y_{11}$ & $20-30$ & Hayır & $30 \mathrm{dk}$ (yarım saat) & $1-15$ \\
\hline Kişi6 & Erkek & Eğitim Fak & Lisans & $6-10 Y_{11}$ & $31-40$ & Hayır & $180 \mathrm{dk}$ (3 saat ve üzeri) & $16-30$ \\
\hline Kişi7 & Erkek & Eğitim Fak & Lisans & $6-10 Y_{11}$ & $20-30$ & Hayır & $61-120 \mathrm{dk}$ (2 saat) & 46 üzeri \\
\hline Kişi8 & Erkek & Eğitim Fak & Lisans & $6-10 Y_{11}$ & $20-30$ & Hayır & $61-120 \mathrm{dk}$ (2 saat) & $31-45$ \\
\hline Kişi9 & Kadın & Eğitim Fak & Lisans & $1-5 Y_{1}$ & $31-40$ & Hayır & $180 \mathrm{dk}$ (3 saat ve üzeri) & $31-45$ \\
\hline Kişi10 & Kadın & Eğitim Fak & Lisans & $1-5$ Yil & $20-30$ & Hayır & $61-120 \mathrm{dk}$ (2 saat) & $31-45$ \\
\hline Kişi11 & Erkek & Eğitim Fak & Lisans & $1-5$ Yil & $20-30$ & Hayır & $180 \mathrm{dk}$ (3 saat ve üzeri) & $31-45$ \\
\hline Kişi12 & Erkek & Eğitim Fak & Lisans & 6-10 Y1l & $20-30$ & Hayır & $31-60 \mathrm{dk}$ (1 saat) & 46 üzeri \\
\hline Kişi13 & Erkek & Eğitim Fak & Lisans & $1-5 Y_{1} 1$ & $20-30$ & Hayır & $31-60 \mathrm{dk}$ (1 saat) & $31-45$ \\
\hline Kişi14 & Erkek & Eğitim Fak & Lisans & $1-5 Y_{1}$ & $20-30$ & Hayır & $180 \mathrm{dk}$ (3 saat ve üzeri) & $16-30$ \\
\hline Kişi15 & Kadın & Eğitim Fak & Lisans & $11-15 \mathrm{Y}_{1}$ & $31-40$ & Hayır & $30 \mathrm{dk}$ (yarım saat) & $31-45$ \\
\hline Kişi16 & Erkek & Eğitim Fak & Lisans & $6-10 Y_{11}$ & $31-40$ & Hayır & $61-120 \mathrm{dk}$ (2 saat) & $31-45$ \\
\hline Kişi17 & Kadın & Eğitim Fak & Lisans & $6-10 Y_{11}$ & $20-30$ & Hayır & $31-60 \mathrm{dk}$ (1 saat) & $16-30$ \\
\hline Kişi18 & Kadın & İlahiyat Fak & Lisans & $1-5$ Yil & $20-30$ & Hayır & $30 \mathrm{dk}$ (yarım saat) & $31-45$ \\
\hline Kişi19 & Kadın & Eğitim Fak & Lisans & $1-5$ Yil & $20-30$ & Hayır & $180 \mathrm{dk}$ (3 saat ve üzeri) & $31-45$ \\
\hline Kişi20 & Kadın & Eğitim Fak & Lisans & 6-10 Yil & $31-40$ & Hayır & $61-120 \mathrm{dk}$ (2 saat) & $31-45$ \\
\hline
\end{tabular}

Çalışma grubunu oluşturan öğretmenlerin kimlikleri gizlenmiş her birine Kişi 1'den Kişi 20'ye kadar kod isim verilmiştir. Çalışma grubu yirmi öğretmenden oluşmuştur. Katılımcıların 9'u kadın, 11'i erkektir. Kıdem durumuna göre 11 öğretmenin 1-5 yıl, 8 öğretmenin 6-10 yıl ve 1 öğretmenin 11-15 yıl kıdeme sahip olduğu görülmektedir. Yaş durumuna göre 14 öğretmenin 20-30 yaş arasında olduğu, 6 öğretmenin 31-40 yaş arasında olduğu görülmüştür.

Öğretmenlerden biri hariç tamamının eğitim fakültesi mezunu olduğu, 1 kişinin ise ilahiyat fakültesi mezunu olduğu, tüm katılımcıların lisans mezunu olduğu, hiçbirinin üniversite eğitiminde uzaktan eğitimle ilgili bir ders almadığı anlaşılmıştır.

Katılımcılardan 3 öğretmenin 30 dakika, 5 öğretmenin 31-60 dakika arası, 6 öğretmenin 61-120 dakika arası, 5 öğretmenin 180 dakika üzeri günlük olarak uzaktan eğitime zaman ayırdığını belirttiği anlaşılmıştır. Katılımcılardan 1 öğretmenin sınıfinda 1-15 arası öğrenci, 4 öğretmenin sinıfinda 16-30 arası öğrenci, 12 öğretmenin sınıfında 31-45 arası öğrenci ve 3 öğretmenin sınıfında 46 üzeri öğrenci olduğu anlaşılmıştır. 


\subsection{Veri Toplama Aracı}

Veri toplama aracı olarak, araştırmacı tarafından geliştirilen açık uçlu sorulardan oluşan yarı yapılandırılmış görüşme formu kullanılmıştır. Veri toplama aracı için öncelikle literatür taraması yapılmış ve konu kapsamındaki temalar bulunmaya çalışılmıştır. Ardından bu temaları ortaya çıkarıcı 17 sorudan oluşan bir soru havuzu oluşturulmuştur. Soru havuzu 4 kişiden oluşan bir uzman görüşüne sunulmuş ve netice olarak 9 sorunun konuyu açıklığa kavuşturucu olduğuna karar verilerek "Şanlıurfa'da İlkokullarda Görev Yapan Öğretmenlerin Covid19 Sürecinde Yürütülen Eğitim Faaliyetlerine İlişkin Görüşleri’” adıyla bir görüşme formu oluşturulmuştur. Görüşme formunu müteakip araştırmanın bünyesinde yapıldığı üniversiteniz sosyal bilimler etik kuruluna başvuru yapılmış ve etik kurul izni alınarak (13.11.2020 tarih ve 2020/92 sayılı) çalışmaya ek yapılmıştır. Veri toplama aracı cinsiyet, mezun olunan kurum, mezuniyet durumu, mesleki kıdem, katılımcı yaşı, üniversite eğitiminde uzaktan eğitim içerikli bir ders alınıp alınmadığı, uzaktan eğitime günlük olarak ayrılan zaman ve sınıfındaki öğrenci sayısı değişkenlerini içermektedir. Araştırma kapsamında sorulan sorular ise şunlardır:

1. Millı̂ Eğitim Bakanlığı’nın Covid19 sürecindeki kriz yönetim politikasını nasıl buluyorsunuz?

2. Covid19 süreci eğitim faaliyetlerine kolayca intibak sağlayabildiniz mi?

3. Sizin ve öğrencilerinizin uzaktan eğitim için gerekli ekipmana sahip olmasına dair ne düşünüyorsunuz?

4. Uzaktan eğitim kapsamında yürütülen eğitim faaliyetlerinin etkililiği hakkında ne düşünüyorsunuz?

5. Daha iyi bir uzaktan eğitim için önerileriniz nelerdir?

6. Millî Eğitim Bakanlığı'nın sunduğu EBA gibi eğitim portallarını ne ölçüde kullanabildiniz? Bu portalların etkililiği hakkında ne düşünüyorsunuz?

7. Uzaktan eğitim faaliyetlerini yüz yüze eğitim ile karşılaş̧ırdığınızda, uzaktan eğitimin veli, öğretmen ve öğrenci açısından maliyeti konusundaki düşünceleriniz nelerdir?

8. Yüz yüze eğitim faaliyetlerine başlanması ile ilgili düşünceleriniz nelerdir?

9. Öğretmenlerin ve okul yöneticilerinin uzaktan eğitim faaliyetlerine dair becerilerine ilişkin gözlemleriniz nelerdir?

\subsection{Veri Toplama Süreci}

Araştırma için gereksinim duyulan veriler araştırmacı tarafından yüz yüze veya uzaktan görüşme firsatı sunan programlar vasıtası ile toplanmıştır. Ayrıca öğretmenlerle gerçekleştirilen görüşmelerde soruların anlaşılır olması için gerekli açıklamalar yapılmış, süre kısıtlamasına gidilmemiştir. Yapılan bu ön görüşmeler sırasında görüşme sorularında yer alan bazı olumsuzluklar düzeltilmiştir. Bu görüşme soruları çeşitli sondalarla zenginleştirilerek öğretmenlere yöneltilmiştir. Görüşme sürecinde veriler, ses kayıt cihazları kullanılarak ve görüşme esnasında araştırmacı tarafından notlar alınarak kayıt altına alınmışıır. Bütün katılımcılara elde edilecek verilerin sadece bilimsel amaçla kullanılacağına dair bilgi verilmiştir. İsteyen katılımcının istediği zaman görüş belirtmeyi bırakabileceği ifade edilmiştir.

\subsection{Verilerin Çözümlenmesi}

Araştırmada toplanan veriler, betimsel analiz ve içerik analizi teknikleri kullanılarak analiz edilmiştir. Betimsel analizde elde edilen veriler, önceden belirlenen temalara göre özetlenir ve yorumlanırken, içerik analizinde ise yorumlanan veriler daha detaylı bir şekilde incelenir ve betimsel yaklaşımla fark edilmeyen kavram ve temalar keşfedilir (Yıldırım ve Şimşek, 2011). Bu çalışmada araştırmanın verileri araştırmacı tarafından derinlemesine incelenerek, elde edilen kategoriler karşılaştırılmış, alan uzmanlarının görüşü alınarak üzerinde uzlaşılan kategoriler oluşturulmuştur.

\section{Bulgular}

Bulgular başlığı altında "İlkokullarda Görev Yapan Öğretmenlerin Covid19 Sürecinde Yürütülen Eğitim Faaliyetlerine İlişkin Görüşlerine" yönelik öğretmen algıları ifade edilmiştir.

\subsection{MEB'nın Covid19 Sürecindeki Kriz Yönetim Politikası}

“Millî Eğitim Bakanlı̆̆ı'nın Covid19 sürecindeki kriz yönetim politikasını nasıl buluyorsunuz?”, sorusuna verilen cevaplar elde edilen verilere göre dört başlık altında toplanmaktadır. Verilen cevapların frekans sayıları Tablo 2'de gösterilmiştir.

Tablo 2: MEB'nın Covid19 sürecindeki kriz yönetim politikasını değerlendirme

\begin{tabular}{lc}
\hline Tema & f \\
\hline Başarılı & 15 \\
\hline Yetersiz & 3 \\
\hline Kapsamlı değil & 1 \\
\hline Sorunlu & 1 \\
\hline
\end{tabular}

Katılımc1 grubun araştırma sorusuna verdiği cevaplar incelendiğinde 4 farklı kategoride dağılım gösterdiği görülmüştür. Katılımc1 öğretmenlerin MEB'nın Covid19 sürecindeki kriz yönetim politikası değerlendirme hakkında "Başarılı" (15 kişi), "Yetersiz" (3 kişi), "Kapsamlı değill" (1 kişi) ve "Sorunlu" (1 kişi) biçiminde 
cevaplar verdikleri görülmektedir. Bu kategoriler değerlendirildiğinde "başarılı" kategorisi bariz bir şekilde diğer kategorilerden ayrışmıştır. Bu kapsamda öğretmenlerin verdiği cevaplardan bazıları aşağıda verilmiştir.

"Millı̂ Eğitim Bakanlığı'nın Covid19 sürecindeki kriz yönetim politikasını nasıl buluyorsunuz?", sorusuna

"Başarılı" kategorisinde verilen örnek öğretmen ifadeleri aşağıdaki gibidir:

Kişi2: "Pandemi sürecinin başlarında EBA'da yaşanan aksakliklar dışında uzaktan eğitim sürecini Bakanlık başarllı bir şekilde yürütmüş̧ür. 2020/2021 Eğitim Öğretim Yılı başlayınca işleyişte yaşanan belirsizlikler zamanla netleşmiş ve rayına oturmuştur." Kişi4: "illk virüs vakası 2020 Mart ayında ülkemizde görüldüğünde panikle okulların kapatıldı̆̆ını ve alt yapımızın henüz hazır olmadan doğrudan uzaktan eğitime geçildiğini düşünüyorum. Bununla birlikte birç̧ok öğrencimizin mağduriyet yaşadı̆̆ııı gördük. 20202021 eğitim ögretim yılında ise daha hazırlıklı daha planl șekilde hareket edildiğini gördük. Hal böyle olunca velilerimizde çocuklarını rahatllkla okula gönderme kararı aldılar. Bu açıdan yeni eğitim öğretim yılında Millı Eğitim Bakanlığı'mızın daha başsarılı olduğunu düşünüyorum."

"Yetersiz" kategorisinde verilen örnek öğretmen ifadeleri aşağıdaki gibidir:

Kişi6: "Ülkemizde de Covid19 vakalarının yaşanacağı aylar öncesinden belliydi ve ülke olarak özellikle de Sağllk Bakanlığı bu konuda tüm hazırlıklarını ve tedbirlerini aylar öncesinden başarıll bir şsekilde tamamlarken ve özellikle Sağlık Bakanlı̆̆ı'nın koordineli çalışması ve almış olduğu tedbirler dünyada nam salmışken maalesef Milli Eğitim Bakanlı̆̆ının kriz yönetimi fikrimce bu konuda yetersiz kalmıştır."

"Kapsamlı Değil" kategorisinde verilen örnek öğretmen ifadeleri aşağıdaki gibidir:

Kişi10: "Kriz yönetimi kapsaml değildi. Alınan önlemler genellikle merkezi okullara yönelikti. Köy okullarında alınan önlemleri gerçekleştirmek çok zor. Uzaktan eğitimle köylerdeki öğrencilere ulaşmak çok zordu."

"Sorunlu" kategorisinde verilen örnek öğretmen ifadeleri aşağıdaki gibidir:

Kişi14: "Uygulanan politikanın ülkenin sosyolojik ve ekonomik yapısına çok da uymadığına ve bu durumun çeşitli sorunlara yol açtı̆̆ıı düs̆̈̈nüyorum."

\subsection{COVİD19 Süreci Eğitim Faaliyetlerine İntibak}

"Covid19 süreci eğitim faaliyetlerine kolayca intibak sağlayabildiniz mi?", sorusuna verilen cevaplardan elde edilen veriler iki başlık altında toplanmaktadır. Verilen cevapların frekans sayıları Tablo 3'te gösterilmiştir.

Tablo 3: Covid19 süreci eğitim faaliyetlerine kolayca intibak sağlama

\begin{tabular}{ll}
\hline Tema & f \\
\hline Evet & 7 \\
\hline Hayır & 13 \\
\hline
\end{tabular}

Katılımcı grubun araştırma sorusuna verdiği cevaplar incelendiğinde 2 farklı kategoride dağılım gösterdiği görülmüştür. Katılımcı öğretmenlerin Covid19 süreci eğitim faaliyetlerine kolayca intibak sağlama hakkında "Evet" (7 kişi), "Hayır" (13 kişi) biçiminde cevap verdikleri görülmektedir. Bu kategoriler değerlendirildiğinde "hayır" kategorisi diğer kategoriden ayrışmıştır. Bu kapsamda öğretmenlerin verdiği cevaplardan bazıları aşağıdaki gibidir:

"Covid19 süreci eğitim faaliyetlerine kolayca intibak sağlayabildiniz mi?", sorusuna "Evet" kategorisinde verilen örnek öğretmen ifadeleri aşağıdaki gibidir:

Kişi6: "Evet birçok teknolojik imkanlar sayesinde Covid19 süreci eğitim faaliyetlerine kolayca intibak sağlayabildim." Kişi\&: "Evet sağlayabildim. Illk başlarda uzaktan eğitimin zorluklart olduysa da zamanla üstesinden gelerek sisteme ayak uydurdum." Kişi16: "Evet her şey çok ş̧effaf bir şekilde yapıldl..."

"Hayır" kategorisinde "zordu ama alışım" ş̧eklinde cevap veren örnek öğretmen ifadeleri aşağıdaki gibidir: Kişi19: "Kolay olduğunu söyleyemem. Zaman alan bir süreçti ama uyum sağladim. Kendimin ve çevremdekilerin sağllğını düşünerek sinıfim için gerekli düzenleme ve uyarllart yaptım."

"Hayır" kategorisinde "iletişim sıkıntısı" ş̧eklinde cevap veren örnek öğretmen ifadeleri aşağıdaki gibidir: Kişi1, Kişi2, Kişi3, Kişsi7, Kişi 10 ve Kişi20: "Covid19 süreci eğitim faaliyetlerine kolayca intibak sağlayamadım çünkü görev yaptı̆̆ım bölgenin sosyo-ekonomik şartları düşük seviyededir. Ögrencilerim ve aileleriyle internet $v b$. araçlarla devaml iletişim halinde olamadım. Imkanları sinırlı olan ögrencilerim açmış olduğum canlı derslere büyük oranda katılım sağlayamad. Bir iki derse katılan ögrrencilerim bile daha sonrasinda internet paketleri bittiği için diğer derslere katılamadı. Bu süreçte benim 
ĕgitimimden mahrum kalan, evde ailelerinden de yeterli desteği alamayan ögrencilerim; bırakın ileriye gitmeyi öğrendiği bilgileri bile unuttu. Bazl öğrencilerim ĕgitim öğretim hayatının önemli aşamalarından birisi olan 1. sınıfta okuma yazma becerilerini tamamlayamadan yüz yüze ĕgitime ara verildi. Bu süreci tamamlayan öğrencilerimden bazllarl da uzaktan ĕgitim sürecinde gerekli desteği alamadı̆̆ için ilerleyemedi, hatta geriledi. Daha önce uzaktan eğitimle ilgili tecrübe sahibi olmamamdan ve EBA'ya dair gerekli donanıma ulaşamamış olmamdan kaynaklı bazı acemilikler yaşadım. Aldı ğımız üniversite eğitimi uzaktan eğitime kolayca intibak sağlayacă̆ımı bir eğitim değil. Bu durum beraberinde birçok sorunu getirdi. Sürecin bizi en çok zorlayan kısmı, en sıkıntılı ve hatta en üzücü kısmı ise Eyyübiye ilçemizin bir kısmının MTI (Mevsimlik Tarım Isççleri) olması, yarısına yakınının ya da daha fazlasının maddi imkanının kısıtlı olması ve bu sebeplerden ötürü canlı derslere katılım oranının çok düşük olması olmuştur. Öncelikle görev yaptığım şehir ve çalıştığım okul mevki itibariyle Covid19 sürecine uyum sağlamada zorlandı̆̆ımı söyleyebilirim. Çünkü çalıştı̆̆ım okul bir köy okulu ve çeşitli yönlerden dezavantajlı. Gerekli altyapı eksikliği çok net hissedilmekte. Köyde çalıştı̆̆ım için çok zorlandım. Çünkü ögrencilerim uzaktan eğitime katılmıyorlar veya katılamıyorlar. " biçiminde görüş ifade etmişlerdir.

\subsection{Uzaktan Eğitim İçin Gerekli Ekipmana Sahip Olma}

"Sizin ve öğrencilerinizin uzaktan eğitim için gerekli ekipmana sahip olmasına dair ne düşünüyorsunuz?" sorusuna verilen cevaplardan elde edilen verilere göre cevapların frekansları Tablo 4'de gösterilmiştir.

Tablo 4: Öğretmen ve öğrencilerin ekipmana sahip olması durumu

\begin{tabular}{llc} 
& Tema & f \\
\hline \multirow{2}{*}{ Öğretmen açısından } & Sahip & 12 \\
\cline { 2 - 3 } & Sahip değil & 8 \\
\hline \multirow{2}{*}{ Öğrenci açısından } & Sahip & 0 \\
\cline { 2 - 3 } & Sahip değil & 20 \\
\hline
\end{tabular}

Tablo 4'e bakıldığında öğretmen ve öğrencilerin ekipmana sahip olması hakkında öğretmen açısından sahip (12 kişi), sahip değil (8 kişi); öğrenci açısından sahip değil (20 kişi) biçiminde cevaplar verildiği görülmektedir. Nerdeyse tüm öğretmenlerin öğrencilerinin gerekli ekipmana sahip olmadığını beyan etmiş olması dikkat çekmektedir. Bu durum araştırmanın yapıldığı bölgenin sosyo-ekonomik durumu ile açıklanabilir. Bölge düşük gelir grubuna sahip öğrencilerin ikamet ettĭ̆i bir yerdir. Bu kategoriler değerlendirildiğinde "sahip değil" kategorisi bariz bir şekilde diğer kategorilerden ayrışmıştır. Bu kapsamda öğretmenlerin verdiği cevaplardan bazıları aşağıdaki gibidir:

"Sizin ve öğrencilerinizin uzaktan eğitim için gerekli ekipmana sahip olmasına dair ne düşünüyorsunuz?", sorusuna öğretmenlerin tamamı öğrenciler açısından "sahip değil” şeklinde cevap vermiştir. Örnek öğretmen ifadeleri aşağıdaki gibidir:

Kişi12, Kişi3 ve Kişi8: "Birçok öğrencim fiziki imkansızlıklardan dolayl derslere katılamadı. Ekipmanı olanlar bile internet bağlantısı yönünden sıkıntı yaşadılar. Öğrenci velisinin ekonomik düzeyi, ĕgitim düzeyi, çocuklara olan ilginin azlı̆̆l ve internet altyapısının köyde yetersiz olması gibi etkenleri stralayabiliriz."

Öğretmenler açısından "sahip değil”" şeklinde verilen örnek öğretmen ifadeleri aşağıdaki gibidir:

Kişi9 ve Kişi7 "Aynı şey benim içinde geçerli. Internete bağlanma ve paket eksikliği yeri geldi sıkıntı yarattı. Çok yetersizdik bu konuda. Çünkü köyde internet yok. Internetin olmadı̆̆ yerde diğerlerinden bahsetmeye gerek yok."

Öğretmenler açısından "sahip" şeklinde verilen örnek öğretmen ifadeleri aşağıdaki gibidir:

Kişi1, Kişi7 ve Kişi8: "Ben uzaktan eğitim adına gerekli teknik ekipmanlara sahiptim. Ben çok lüks imkanlara sahip olmasam da uzaktan ĕgitim sürecine yetecek kadar imkanlara sahibim. Ama ..." biçiminde görüş beyan etmişlerdir.

\subsection{Uzaktan Eğitim Kapsamında Yürütülen Eğitim Faaliyetlerinin Etkililiği}

“Uzaktan eğitim kapsamında yürütülen eğitim faaliyetlerinin etkililiği hakkında ne düşünüyorsunuz?” sorusuna verilen cevaplardan elde edilen bulgular dört başlık altında toplanmaktadır. Verilen cevapların frekansları Tablo 5 'te gösterilmiştir. 
Tablo 5: Uzaktan eğitim kapsamında yürütülen eğitim faaliyetlerinin etkililiği hakkında görüşler

\begin{tabular}{lc} 
Tema & f \\
\hline Etkili & 2 \\
\hline Kısmen & 6 \\
\hline Etkili değil & 11 \\
\hline Cevap vermeyen & 1 \\
\hline
\end{tabular}

Katılımcı grubun araştırma sorusuna verdiği cevaplar incelendiğinde 4 farklı kategoride dağılım gösterdiği görülmüştür. Tablo 5'e bakıldığında katılımcı öğretmenlerin uzaktan eğitim kapsamında yürütülen eğitim faaliyetlerinin etkililiği hakkında "etkili" (2 kişi), "kısmen" (6 kişi) ve "etkili değil” (11 kişi) biçiminde cevaplar verdikleri görülmektedir. Bu kategoriler değerlendirildiğinde "etkili değil” kategorisi bariz bir şekilde diğer kategorilerden ayrılmıştır. Bu kapsamda öğretmenlerin verdiği cevaplardan bazıları aşağıdaki gibidir:

"Uzaktan eğitim kapsamında yürütülen eğitim faaliyetlerinin etkililiği hakkında ne düşünüyorsunuz?” sorusuna "Etkili değil" kategorisinde "Yüz yüze eğitimin yerini tutmuyor" nedeniyle beş kişi, "teknik altyapı ve imkânsızlık" nedeniyle diyen dört kişi cevap vermiştir. Kalan iki kişi neden belirtmemiştir.

Etkili değil" kategorisinde Kişi1, Kişi8 ve Kişi14 "Yüz yüze eğitimin yerini tutmuyor. Öğrencilerin ögrretmenle aynı ortam içerisinde, birebir göz teması kurarak ders işlemesi, okul ortamında arkadaşlarıyla sosyalleşerek bir şeyler öğrenmesi son derece önemlidir. Sınıfın yarısından fazlası katılamadı̆̆ından etkili değil. Diğer öğrenciler derslerden geri kallyor. Katılanlar için ise yüz yüze eğitimdeki kadar etkili olmuyor. Ayrıca her çocuğun derse katıldı ̆̆ ortam onlar için uyarıcı olmuyor, aksine derse adapte olmasını zorlaştırabiliyor. Sistemsel hatalar yaşamasak etkili olabilir ancak şu anki durumda etkili olamıyor. Ayrıca bizim bölgemiz için pek etkili olmadı. Uzaktan eğitimin etkililiği bence tamamen imkanlarla ilgili. Öğrencilerin çoğunluğunda imkân yok” biçiminde görüş beyan etmişlerdir.

"Kısmen" kategorisinde Kişi2, Kişi6, Kişi10 ve Kişi13 "Uzaktan ĕgitim faaliyetlerinin sosyo-ekonomik düzeyi yüksek olan bölgelerde verimli geçtiğini düşünüyorum. Çünkü bilinçli veli profili ve yeterli imkana sahip ögrencilerden oluşmaktadır ama bazı dezavantajlı bölgelerde bu faaliyetlerin amacına yeterince ulaşabildiğini düşünmüyorum. Örneğin bazı bölgelerde uzaktan eğitime katılım yüzde doksan iken benim çalıştı̆̆ım bölgede yüzde on civarındadır. Uzaktan eğitim faaliyeti daha çok bilinçli veli ve ögrenciler için faydalı olmuştur. Bazı kademelerde ve derslerde etkili oldu. Ancak matematik, ilk okuma yazma gibi derslerde uzaktan eğitim çok etkili olmadl. Uzaktan eğitimde kalıcı ögrenmelerde zorluk yaşandl. Uzaktan ĕgitim faaliyeti biz ögretmenlerde özellikle sınıf ögretmenlerinde çok zor geçti. Çocukların katılmaması bir yana çocukların somut dönemde olması bu süreci daha da zorlaştırdı." biçiminde görüş beyan etmişlerdir.

“Etkili”" kategorisinde Kişi15 ve Kişi16 "Illk başlarda sıkıntı yaşandı ama şu anda yüz yüze ĕgitimin kismen de başlaması uzaktan ĕ̆itimi daha verimli hale getirdi. EBA TV yayınları ve EBA uygulamasının içeriği çok ögretici. ” biçiminde görüş beyan etmişlerdir.

Günümüzdeki uzaktan eğitim süreçleri henüz yüz-yüze uygulamalara bütünüyle alternatif olamamaktadır (Tuncer ve Bahadır, 2017). Bu aşamada yüz-yüze eğitimde sağlanan etkileşim boyutu, uzaktan eğitim için en önemli eksiklik olarak dile getirilebilir. Kaysi ve Aydemir (2017) çalışmalarında uzaktan eğitimdeki tüm etkileşim boyutlarının düşük düzeyde kaldığını belirlemiştir. Diğer bir ifadeyle uzaktan eğitim süreçlerinde yüz-yüze sınıflardaki gibi bir etkileşim elde edilememektedir (Huss, Sela ve Eastep, 2015). Bu sorun da beklenen verimin ve çıktıların elde edilememesine neden olabilmektedir. Türkiye'de son yıllarda uzaktan eğitim birimlerinin sayısı artmasına rağmen beklenen verimin elde edilemediği sonucuna ulaşılmıştır (Gülnar, 2008). Özellikle bu aşamada uzaktan eğitim süreçlerindeki ögrencilerin ciddiyetsiz olduğu ve bu öğrencilerin etkileşim ve motivasyon eksiklikleri yaşadıkları belirlenmiştir (Panchabakesan, 2011).

\subsection{Uzaktan Eğitim İçin Öneriler}

“Daha iyi bir uzaktan eğitim için önerileriniz nelerdir?” sorusuna verilen cevaplardan elde edilen bulgular üç başlık altında toplanmaktadır. Verilen cevapların frekans sayıları Tablo 6'da gösterilmiştir. 
Tablo 6: Daha iyi bir uzaktan eğitim için beyan edilen öneriler

\begin{tabular}{lc}
\hline Tema & f \\
\hline Altyapı ve ekipman eksikliğinin giderilmesi & 20 \\
\hline Ailelerin bilinçlendirilmesi & 2 \\
\hline MEB'in kendi platformlarını kurması & 1 \\
\hline
\end{tabular}

Katılımcı grubun araştırma sorusuna verdiği cevaplar incelendiğinde 3 farklı kategoride dağılım gösterdiği görülmüştür. Bu kategorilere katılımcılar “altyapı ve ekipman eksikliğinin giderilmesi” (20 kişi), "ailelerin bilinçlendirilmesi” (2 kişi) ve "MEB'in kendi platformlarını kurması" (1 kişi) biçiminde cevaplar vermiştir. Katılımcı gruptan 3 kişi birden fazla öneride bulunmuştur. Bu kategoriler değerlendirildiğinde "altyapı ve ekipman eksiğinin giderilmesi” kategorisi bariz bir şekilde diğer kategorilerden ayrışmıştır. Bu kapsamda öğretmenlerin verdiği cevaplardan bazıları aşağıdaki gibidir:

“Daha iyi bir uzaktan eğitim için önerileriniz nelerdir?” sorusuna bazı öğretmenler birden fazla cevap vermişlerdir. “Altyapı ve ekipman eksikliğinin giderilmesi” kategorisinde tüm öğretmenler hemfikirdir. Bu kategoride verilen örnek öğretmen ifadeleri şöyledir:

"GSM şirketleri ve Milli Ĕgitim işbirliği ile her çocuğun ĕ̆itim alabileceği ortam oluşturulmall. GSM şirketlerinin EBA'ya girmek için verdiği internet ile çocuklar EBA canll derslere katılamıyor yine kendi internetleri gerekiyor. Bu şekilde bir eğitim yapılacaksa aylar öncesinden hazırlıkları yapılmalı. Tüm mobil hatlar ile anlaşmalar yapılmalı ve ögrencilere yönelik olarak hangi platformdan canlı derse katıliyorsa $O$ platformun ücretsiz olmasl sağlanmalı. Gerekirse ev telefonları üzerinden de televizyon ile bă̆ kurularak, akıllı telefonlar gibi, derse katılabilmeli çocuklar. Çünkü hala bazı ailelerin akıllı telefon alma imkanları yok ya da babaları işe gittiği için derse bağlanamıyorlar. Daha iyi bir uzaktan eğitim için öncelikle çok daha organize çalışmak gerektiğini düşünüyorum. Her evde en azından bir tablet olmasi gibi. Sonrasında ise uzaktan eğitime uygun bir müfredat planlanmall. En önemlisi de operatörler canlı dersler için ücretsiz internet hakkı tanıyabilirler. ” biçiminde görüş beyan etmişlerdir.

“Ailelerin bilinçlendirilmesi” kategorisinde verilen örnek öğretmen ifadeleri aşağıdaki gibidir:

Kişi12 ve Kişi20 "Daha da önemlisi ailelerin ĕgitim ve ögretimin sadece okul adı verilen dört duvarla sınırlı olmadı̆̆ konusunda bilinçlendirilmesi lazım. Bu süreçte pek çok aile gördü ki evde de eğitim-ögretim olabiliyor, aileler ögretmen rolünü üstlenebiliyor. Aileler bu konuda ne kadar duyarl davranırsa ögrencilerde ögrenmeye bir o kadar istekli oluyor. Evdeki öğrenci velilerinin ilgili olması gerekiyor.” biçiminde görüş beyan etmişlerdir.

3.6. EBA gibi Eğitim Portallarını Kullanma ve Etkililiği

“Millî Eğitim Bakanlığı'nın sunduğu EBA gibi eğitim portallarını ne ölçüde kullanabildiniz. Bu portalların etkililiği hakkında ne düşünüyorsunuz?" sorusuna verilen cevaplardan elde edilen bulgular iki başlık altında toplanmaktadır. Verilen cevapların frekansları Tablo 7'de gösterilmiştir.

Tablo 7: EBA portalının kullanımına ve etkililiğine ilişkin görüşler

\begin{tabular}{ll}
\hline Tema & f \\
\hline Öğrenci girişi az & 11 \\
\hline Faydalı & 13 \\
\hline Canlı ders imkânı & 2 \\
\hline İçerik az, arttırılmalı & 5 \\
\hline Mesleki gelişime katkı sağlıyor & 2 \\
\hline Eğlenceli & 1 \\
\hline Araştırmaya yöneltiyor & 1 \\
\hline İçerik paylaşımı & 1 \\
\hline
\end{tabular}

Katılımcı grubun araştırma sorusuna verdiği cevapların 8 farklı kategoride dağılım gösterdiği görülmüştür. "Öğrenci girişi az” (11 kişi), "Faydalı" (13 kişi), “canlı ders imkânı” (2 kişi), "içerik az, arttırılmalı” (5 kişi), "mesleki gelişime katkı sağlıyor” (2 kişi), "eğlenceli” (1 kişi), “Araştırmaya yöneltiyor” (1 kişi) ve "içerik paylaşımı" (1 kişi) biçiminde görüş beyan edilmiştir. Bu kategoriler değerlendirildiğinde "öğrenci girişi az” ve "faydalı" kategorisi bariz bir şekilde diğer kategorilerden ayrışmıştır. Bu kapsamda öğretmenlerin verdiği cevaplardan bazıları aşağıdaki gibidir:

“Millî Eğitim Bakanlığı'nın sunduğu EBA gibi eğitim portallarını ne ölçüde kullanabildiniz. Bu portalların etkililiği hakkında ne düşünüyorsunuz?” sorusuna bazı öğretmenler birden fazla cevap vermişlerdir.

“Öğrenci Girişi Az” kategorisinde verilen örnek öğretmen ifadeleri aşağıdaki gibidir: 
Kişi8, Kişi20 ve Kişi13: “Öğrencilerin EBA'ya giriş yapabilmesi sağlanırsa bu portalın daha etkili olacağını düşünüyorum. Tabikî bu da öğrencilerin cihaz ihtiyacının giderilmesiyle mümkün olacaktır. Öğrencilerimin internet konusunda yaşadı̆̆l sıkıntılar uzaktan eğitimi başarıyla icra etmemize engel oldu..." biçiminde görüş beyan etmişlerdir.

"Yararlı/Faydalı" kategorisinde verilen örnek öğretmen ifadeleri aşağıdaki gibidir:

Kişi3, Kişi4 ve Kişi6: “EBA'nın çok faydalı olduğunu düşünüyorum. Mümkün olduğunca bu platformdan yararlandık. EBA gibi ĕgitim portallarını çok etkili ve verimli kullanabildim. Bu portallarda yeterince bilgi yüklenmişti.” biçiminde görüş beyan etmişlerdir.

“Araştırma", "Canlı Ders" ve "İçerik Paylaşma” kategorisinde verilen örnek öğretmen ifadeleri aşağıdaki gibidir:

Kişi1 ve Kişi19: "EBA'yı araştırma, içerik paylaşımı, canlı ders yapma vb. için kullanmaya çalıştım. Canlı derslerimizi EBA platformu üzerinde gerçekleştirdik. İlk haftalardaki teknik sorunlarl saymazsak canlı ders işlemek için etkili olarak kullanabiliyorum. Istediğim zamanda ders oluşturup işleyebiliyorum. ” biçiminde görüş beyan etmişlerdir.

“İçerik fazlalaştırılması” ve "Mesleki Gelişim” kategorisinde verilen örnek öğretmen ifadeleri aşağıdaki gibidir: Kişi1 ve Kişi10: "EBA içerisinde birçok bilgi, belge ve dokümanı barındıran bir platform ama 2. sınıflarla ilgili ders içeriği çok az. Özellikle kütüphanede yer alan zekâ oyunları ile ilgili videolar sayesinde kendimi geliştirme imkânı buldum. Mesleki gelişim alanında ise istediğim alanlarla ilgili uzaktan ĕgitim kurslarına EBA üzerinden kolaylıkla katılım sağlayabildim. " biçiminde görüş beyan etmişlerdir.

\subsection{Uzaktan Eğitimin Maliyeti Konusundaki Düşünceler}

"Uzaktan eğitim faaliyetlerini yüz yüze eğitim ile karşılaştırdığınızda, uzaktan eğitimin veli, öğretmen ve öğrenci açısından maliyeti konusundaki düşünceleriniz nelerdir?" sorusuna verilen cevaplardan elde edilen veriler tek başlık altında toplanmaktadır. Verilen cevapların frekansları Tablo 8'de gösterilmiştir.

Tablo 8: Uzaktan eğitimin maliyeti konusunda düşünceler

\begin{tabular}{lc}
\hline Tema & f \\
\hline Uzaktan eğitim daha maliyetlidir & 20 \\
\hline
\end{tabular}

Katılımcı grubun araştırma sorusuna verdiği cevap incelendiğinde tüm cevapların 1 kategoride toplandığ görülmüştür. Tüm katılımcılar (20 kişi) Covid19 nedeniyle yürütülen eğitim faaliyetlerin maliyetleri konunda "yüksek maliyetlidir" biçiminde görüş beyan etmişlerdir. Buna gerekçe olarak da "internet ve cihaz" maliyetini ifade etmişlerdir. İnternet ve cihazın maliyetli bulunması araştırmanın yapıldığı alanın sosyo-ekonomik durumu ile açıklanabilir. Bu kapsamda öğretmenlerin verdiği cevaplardan bazıları aşağıdaki gibidir:

"İnternet ve cihazdan dolayı uzaktan eğitim maliyetlidir" kategorisinde tüm öğretmenler hemfikirdir. Bu kategorisinde verilen örnek öğretmen ifadeleri aşağıdaki gibidir:

Kişi7, Kişi11 ve Kişi18: "Uzaktan eğitim maliyet olarak yüz yüze eğitimden çok daha maliyetlidir. Hem internet maliyeti hem ekipman maliyeti olarak çok pahalıdır. Veli açısından bakarsak evden uzaktan eğitim daha zor oldu. Çünkü teknolojik alet eksikliği ve internet sıkıntısı gibi imkanlar ve bununla beraber çoğu ailenin en az 4-5 ve hatta 6 çocuklu olması uzaktan eğitimde veliyi fazlasıla zorladı. MTİ olup farklı il ve ilçelerde çalışan aileler de maddi olarak en çok etkilenen aile gruplarından biri oldu. " biçiminde görüş beyan etmişlerdir.

3.8. Yüz Yüze Eğitim Faaliyetlerine Başlanması ile İlgili Düşünceler

"Yüz yüze eğitim faaliyetlerine başlanması ile ilgili düşünceleriniz nelerdir?" sorusuna verilen cevaplardan elde edilen verilere göre üç başlık altında toplanmaktadır. Verilen cevapların frekansları Tablo 9'da gösterilmiştir.

Tablo 9: Yüz yüze eğitim faaliyetlerinin başlaması ile ilgili düşünceler

\begin{tabular}{lc}
\hline Tema & f \\
\hline Doğru buluyorum & 18 \\
\hline $\begin{array}{l}\text { Covid19 vakalarının artarsa uzaktan eğitim } \\
\text { devam etmeli }\end{array}$ & 1 \\
\hline Daha az öğrenci ile başlanmalı & 1 \\
\hline
\end{tabular}

Katılımcı grubun cevaplarının 3 farklı kategoride dağılım gösterdiği görülmüştür. Bu kategoriler değerlendirildiğinde "doğru buluyorum” (18 kişi), “Covid19 vakalarının artarsa uzaktan eğitim devam etmeli” (1 
kişi), “daha az öğrenci ile başlanmalı” (1 kişi) biçiminde görüş belirtilmiştir. Yüz yüze eğitimin başlaması gerektiğini düşünenlerin sayısı belirgin biçimde fazladır. Bu kapsamda öğretmenlerin verdiği cevaplardan bazıları aşağıdaki gibidir:

"Yüz yüze eğitim faaliyetlerine başlanması ile ilgili düşünceleriniz nelerdir?" sorusuna "Doğru buluyorum" kategorisinde verilen örnek öğretmen ifadeleri aşağıdaki gibidir:

Kişi 1, Kişi3, Kişi15 ve Kişi20: "Yüz yüze e ğitimin başlamasının çalıştı̆̆ım bölge için doğru bir karar olduğunu düşünüyorum. Çünkü bu bölgedeki ögrenciler uzaktan ĕgitimi çeşitli olumsuzluklar yüzünden etkili bir şekilde alamadılar. Katılım çok yetersizdi. Diğer bölgelerde ise uzaktan eğitim faaliyetleri başarılı bir şekilde yürütüldü. Bu durum bölgeler arası eğitim farkında uçurum etkisi yarattı. Yüz yüze eğitimin başlamasının çocuklar için çok yararlı olduğunu düşünüyorum. Insanlar her yerde rahatça dolaşırken; bütün eğlence mekanlarl, tatil merkezleri vb. açıkken; çocuklar sokaklarda keyfince dolaşırken okulların kapalı olması beni rahatsı ediyordu. Okulun sokaklardan daha güvenli olduğunu düşünüyorum. Özellikle salgın riskinin az olduğu köy vb. yerleşim yerlerinde tamamen yüz yüze eğitime geçilmesi yerinde bir karardl. Okullarda hastalık riski olabilir ama bu risk evden çıktı̆̆ımız an her yerde var zaten. Biz büyükler kurallara uyarsak ve çocuklar da azami ölçüde uyduğu sürece yüz yüze eğitimin kapsamı daha da genişletilecektir. Yüz yüze ĕgitim faaliyetlerinin başlamasına elbette ögrencilerini özleyen bir ögretmen olarak çok sevindim. Uzaktan eğitimi çok verimli geçirme şansım olsa belki bu kadar istemeyebilirdim okulların açılışını. Ama ne yazık ki köy okullarında yüz yüze eğitimden başka çare yok. ” biçiminde görüş beyan etmişlerdir.

“Artarsa uzaktan olmalı” kategorisinde verilen örnek öğretmen ifadesi aşağıdaki gibidir:

Kişi5: "Uzaktan eğitimin çok başarılı geçtiğini söyleyemem. Salgının ne zaman geçeceğini bilememekle beraber ĕgitime uzun bir zaman ara vermenin hem ögrenciyi hem de velileri olumsuz etkileyeceği kanaatindeyim. Ĕ̆itimden önce sağlı gelir. Herhangi bir olumsuz durum olduğunda okullara uzaktan eğitim ile devam edilmesi daha doğru olur diye düşünüyorum. Bu konuda Sağlık Bakanımıza ve MEB'e çok büyük işler düşüyor. Hepimiz için en isabetli kararlarl verirler inşallah.” biçiminde görüş beyan etmiştir.

“Daha az öğrenci ile başlanmalı” kategorisinde verilen örnek öğretmen ifadeleri aşağıdaki gibidir: Kişi9: "Sıralı bir şekilde başlaması gerekirdi. Bir anda ilkokul grubunu aynı binada toplamak sıkıntılı bir durum. Özellikle kalabalık okullarda çok daha zor olmakta. Çünkü yaşları itibariyle temizlik alışkanlıkları konusunda sıkıntılı öğrenciler mevcut." biçiminde görüş beyan etmiştir.

\section{Gözlemler}

3.9. Öğretmenlerin ve Okul Yöneticilerinin Uzaktan Eğitim Faaliyetlerine Dair Becerilerine İlişkin

"Öğretmenlerin ve okul yöneticilerinin uzaktan eğitim faaliyetlerine dair becerilerine ilişkin gözlemleriniz nelerdir?” sorusuna verilen cevaplardan elde edilen bulgular altı başlık altında toplanmaktadır. Verilen cevapların frekansları Tablo 10’da gösterilmiştir.

Tablo 10: Öğretmenlerin ve okul yöneticilerinin uzaktan eğitim faaliyetlerine dair becerileri

\begin{tabular}{ll}
\hline Tema & f \\
\hline Elimden geleni yapıyorum & 2 \\
\hline Başta zorlandım ancak şimdi daha iyi & 3 \\
\hline Hızlı şekilde adapte olduk & 9 \\
\hline Rahat kullandılar & 2 \\
\hline Tecrübe ve bilgi yoktu & 3 \\
\hline Cevap yok & 1 \\
\hline
\end{tabular}

Katılımcı grubun araştırma sorusuna verdiği cevaplar incelendiğinde, cevapların 6 farklı kategoride dağılım gösterdiği görülmüştür. Bu kategoriler değerlendirildiğinde "elimden geleni yapıyorum” (2 kişi), "başta zorlandım ancak şimdi daha iyi" (3 kişi), "hızlı şekilde adapte olduk" (9 kişi), "rahat kullandılar" (2 kişi), "tecrübe ve bilgi yoktu" (3 kişi) biçiminde görüş belirtilmişlerdir. Bu kategoriler değerlendirildiğinde "hızlı şekilde adapte oldular" kategorisi bariz bir şekilde diğer kategorilerden ayrışmıştır. Bu kapsamda öğretmenlerin verdiği cevaplardan bazıları aşağıdaki gibidir:

"Öğretmenlerin ve okul yöneticilerinin uzaktan eğitim faaliyetlerine dair becerilerine ilişkin gözlemleriniz nelerdir?” sorusuna “Elinden gelenin en iyisi” kategorisinde verilen örnek öğretmen ifadeleri aşağıdaki gibidir:

Kişi20: "Öğretmenlerin ve okul yöneticilerinin uzaktan ĕgitim faaliyetlerine dair becerilerine ilişkin gözlemlerim genel anlamda olumlu. Okul olarak tüm olumsuz şartlara 
rağmen elimizden gelenin en iyisini yapmaya çalıştık. Keşke veli ve öğrenci desteğini de tam olarak alabilseydik."

"Başta zorlandılar sonra alıştılar" kategorisinde verilen örnek öğretmen ifadeleri aşağıdaki gibidir: Kişi11: "Öğretmen ve okul yöneticilerinin ilk kez karşılaş̧tıkları bir durum olduğu için ne ve nasıl yapılacağı konusunda bir hayli zorluk çekilmişti. Ama kendi çabalarımızla ögrenerek becerilerimizi geliştirmeye çalıştık."

"Hızlı şekilde adapte oldular" kategorisinde verilen örnek öğretmen ifadeleri aşağıdaki gibidir:

Kişi3, Kişi10 ve Kişi19: "Öğretmenlerin ve okul idarecilerinin uzaktan eğitim becerilerini hızl bir şekilde deneyimleyerek ögrendiğini düşünüyorum. Öğretmenler ve okul yöneticileri ilk defa karşılaş̧tıları bu sistemi en doğru şekilde yapmak için elinden geleni yapt. Sürece kisa sürede adapte oldu. Süreci en doğru şekilde hep birlikte işbirliği içinde yürüttü. Bu sürece teknolojik beceriler olarak kolay adapte olduğumuzu düşünüyorum. " biçiminde görüş beyan etmişlerdir.

"Rahat Kullandılar" kategorisinde verilen örnek öğretmen ifadeleri aşağıdaki gibidir:

Kişi7 ve Kişi12: "Okul idaremiz ve okulumuzdaki ögretmenlerin hepsi zaten fazlasiyla teknolojinin içinde olduğu için uzaktan eğitim konusuna çok rahat şekilde alş̧t. Bilgisayar, tablet ve internet kullanımı konusunda zaten gayet iyiydik. EBA'yl zaten kullaniyorduk. Uzaktan eğitimde de gerekli donanım, bilgi ve belge ile okul idaremiz ve ögretmenler olarak rahat bir şekilde üstesinden geldik. Okul idaremiz uzaktan tüm okulu sürekli takip ederek ve de olușturdukları canlı dersler ile gerekeni fazlası ile yaptı. Öğretmenler canlı derslerde gerekeni anlatımlar, testler vb. çoğu şey ile yaptı. Uzaktan eğitim de yaşanan en büyük sikıntılar öğrenci ve veli kaynaklıdır. " biçiminde görüş beyan etmişlerdir.

“Tecrübe/Bilgi yoktu” kategorisinde verilen örnek öğretmen ifadeleri aşağıdaki gibidir:

Kişi14: "Camiadaki birçok insanın konu hakkında yeterli bilgi ve birikime sahip olmadığını gözlemledik. ” biçiminde görüş beyan etmişlerdir.

\section{Sonuç, Tartışma ve Öneriler}

Katılımcı gruba “Millı̂ Eğitim Bakanlığı'nın Covid19 sürecindeki kriz yönetim politikasını nasıl buluyorsunuz?" sorusu yöneltilmiştir. Gelen cevaplardan anlaşıldığı üzere katılımcı grup büyük çoğunlukla kriz yönetimini başarılı bulmuştur. Başarılı bulanların gerekçeleri incelendiğinde bakanlığın canlı ders uygulaması, EBA ve EBA destek noktası gibi çalışmaların katılımcı grubu bu düşünceye ittiği anlaşılmaktadır. Başarısız veya yetersiz bulan katılımcılar ise gerekçe olarak canlı derslerde yaşanan aksamaları ileri sürmüşlerdir.

Katıııcı gruba "Covid19 süreci eğitim faaliyetlerine kolayca intibak sağlayabildiniz mi?" sorusu yöneltilmiş, gelen cevapların büyük ölçüde "hayır" kategorisi altında toplandığı görülmüştür. Öğretmenler alışldık düzende ders anlatmak yerine, etkileşimin ve duygu geçişinin daha zayıf olduğu ve araçlı iletişimin kurulduğu alanlarda eğitim vermek zorunda kalmışlardır. "Hayır" cevabı veren katılımcılar, uzaktan eğitime dair tecrübelerinin olmaması, görev yerlerindeki öğrencilerin yeterli bilişim araçlarına ve altyapısına sahip olmamasını ve kendilerinin bu noktada bir eğitim almamış olmalarını ileri sürmüşlerdir. "Evet" cevabı verenler ise Eğitim Bakanlığı'nın sunduğu araçlardan dolayı böyle düşündüklerini açıklamışlardır.

Katılımcı gruba "Sizin ve öğrencilerinizin uzaktan eğitim için gerekli ekipmana sahip olmasına dair ne düşünüyorsunuz? sorusu yöneltilmiş ve katılımcıların birçoğunun öğrencilerinin bu ekipmana sahip olmadığını ifade etmişlerdir. Araştırmanın yapıldığı bölge dikkate alındığında mevsimlik tarım işçiliğinin yoğun olması, sosyo-ekonomik yapının görece zayıf olmasının bu düşüncelerin ortaya çıkmasında etkili olmuş olduğu söylenebilir.

Katılımcı gruba "Uzaktan eğitim kapsamında yürütülen eğitim faaliyetlerinin etkililiği hakkında ne düşünüyorsunuz?" sorusu yöneltilmiş ve gelen cevaplar değerlendirilmiş̧ir. Buna göre katılımcı grubun görüşleri "etkili değil" noktasında belirginleşmiş̧ir. Bu cevabı veren katılımcıların olumsuz kanaat bildirmesinde uzaktan eğitimin duygusal yönünün zayıf olması etkili olmuş olabilir.

"Daha iyi bir uzaktan eğitim için önerileriniz nelerdir?" sorusuna katılımcı grup, net bir biçimde alt yapının yetersizliğinin giderilmesi olarak cevap vermiş̧ir. Altyapı yetersizliği ise öğretmen görüşlerine göre iki ana noktada toplanmıştır. Bunlar biliş̧im ağından kaynaklanan sorunlar ve öğrencilerin donanımsal eksiklikleridir.

Katılımcı gruba yöneltilen "Millî Eğitim Bakanlığı'nın sunduğu EBA gibi eğitim portallarını ne ölçüde kullanabildiniz? Bu portalların etkililiği hakkında ne düşünüyorsunuz?" sorularına verilen cevaplar iki kategoride belirginleşmiştir. Bu kategoriler "sorun yok" ve "alt yapı yetersiz" olarak verilen cevaplardır. Sorun olmadığını 
düşünen katılımcılar görüşlerini faydalı/ yararlı kategorisinde birleştirmişlerdir. Diğer kategoride gelen cevaplar ise öğrencilerin tam ve etkin katılamadığından kaynaklı şikayetlerdir.

Katılımcı gruba yöneltilen "Uzaktan eğitim faaliyetlerini yüz yüze eğitim ile karşılaştırdığınızda, uzaktan eğitimin veli, öğretmen ve öğrenci açısından maliyeti konusundaki düşünceleriniz nelerdir?” sorusuna gelen cevaplar tek bir kategori altında toplanmıştır. Bu cevaplar değerlendirildiğinde internet tabanlı araçların ve alt yapının maliyetli olması şeklinde bir sonuca ulaşılmıştır. Bu maliyet kalemleri de bilişim alt yapısı ve bu alt yapıda kullanılan araç gereçler şeklinde açıklanmıştır.

"Yüz yüze eğitim faaliyetlerine başlanması ile ilgili düşünceleriniz nelerdir?” sorusuna katılımcı grup genel olarak "doğru buluyorum" biçiminde cevap vermiştir. Doğru bulma nedenleri incelendiğinde ders müfredatından geri kalınması, eksik öğrenmelerle bir üst kademeye geçilmesinin engellenmesi gibi hususlar sıralanmıştır. Ayrıca bazı öğretmenlerin yüz yüze eğitimin daha faydalı olduğunun altını çizdikleri görülmüştür.

Katılımcı gruba "Öğretmenlerin ve okul yöneticilerinin uzaktan eğitim faaliyetlerine dair becerilerine ilişkin gözlemleriniz nelerdir?” sorusu yöneltilmiştir. Verilen cevapların geniş aralıkta dağılım gösterdiği görülse de katılımcıların yarıya yakını, okul yöneticilerinin sürece kolay uyum sağladığını düşündükleri gözlemlenmiştir. Bu durumu gerekçelendiren katılımcıların birbirinden farklı argümanlar kullandığı sonucuna da ulaşılmıştır.

Genel olarak değerlendirildiğinde araştırmanın katılımcısı olan öğretmenlerin başlangıçta zorlansalar da uzaktan eğitim sürecine uyum sağladıkları bulgusuna ulaşılmıştır. Ayrıca katılımcı grup Milli Eğitim Bakanlığı'nın eksiklerine rağmen süreci doğru yürüttüğünü, öğrencilerin bilişim araçları açısından donanım ve erişim konularında sıkıntı çektiğini, öğretmenlerin her şeye rağmen yüz yüze eğitimden yana olduklarını ve yüz yüze eğitim ile uzaktan eğitimi eşdeğer tutmadıkları anlaşılmaktadır.

Sonuç olarak kriz yönetimi bağlamında durum başarılı olarak nitelendirilse de uzaktan eğitim için tam bir imkana sahip olunmadığı anlaşıldığından, Milli Eğitim Bakanlığı bünyesinde bir uzaktan eğitim dairesinin kurulmasının önemli olduğu anlaşılmaktadır. Yine öğretmenlere uzaktan eğitim konusunda hizmet içi eğitimlerin verilmesi, öğretmen ve öğrencilere uzaktan eğitim sürecinin doğru ve eksiksiz yürümesi için donanım desteği sağlanması gerekmektedir. Eğitim materyallerinin çeşitlendirilerek daha etkili hale getirilmesi, özellikle köy gibi kırsal bölgelerde internet altyapısının güçlendirilmesi, ailelerin uzaktan eğitim sürecinin yönetimine dahil edilmesi, uzaktan eğitim faaliyetlerinin sınırlı da olsa ev ziyaretleri ile desteklenmesi önerilebilir.

\section{Kaynakça}

Bozkurt, A. (2017). Türkiye'de Uzaktan Eğitimin Dünü, Bugünü ve Yarını, Açıköğretim Uygulamaları ve Araştırmaları Dergisi, 3(2), 85-124.

Cabı, E. (2016). Uzaktan Eğitimde E-Değerlendirme Üzerine Öğrenci Algıları. Journal of Higher Education \& Science/Yüksekögretim ve Bilim Dergisi, 6(1), 94-101.

Çetinkaya Aydın, G. (2020). COVID19 Salgını Sürecinde Öğretmenler. Tedmem. https://tedmem.org/covid19/covid-19-salgini-surecinde-ogretmenler, Son erişim tarihi: 01 Mayıs 2020.

Daniel, S.J. (2020). Education and the COVID19 pandemic. Prospects, https://doi.org/10.1007/s11125-020$\underline{09464-3}$

Durak, G, Çankaya, S. ve İzmirli, S. (2020). COVID19 Pandemi Döneminde Türkiye'deki Üniversitelerin Uzaktan Eğitim Sistemlerinin İncelenmesi. Necatibey Eğitim Fakültesi Elektronik Fen ve Matematik Eğitimi Dergisi, 14 (1), 787-809 . DOI: 10.17522/balikesirnef.743080

Ekici, G. (2003). Uzaktan Eğitim Ortamlarının Seçiminde Öğrencilerin Öğrenme Stillerinin Önemi. Hacettepe Üniversitesi Ĕgitim Fakültesi Dergisi, Sayı: 24, 48-55.

Gülnar, B. (2008). Bilgisayar ve internet destekli uzaktan eğitim programlarının tasarım, geliştirme ve değerlendirme aşamaları (SUZEP Örneği). Selçuk Üniversitesi Sosyal Bilimler Enstitüsü Dergisi, 19, 259271.

Gürer, M. D., Tekinarsan, E. ve Yavuzalp, N. (2016). Çevrimiçi Ders Veren Öğretim Elemanlarının Uzaktan Eğitim Hakkındaki Görüşleri, Turkish Online Journal of Qualitative Inquiry, 7(1), 47-78.

Huss, J. A., Sela, O. ve Eastep, S. (2015). A Case Study of Online Instructors and Their Quest for Greater Interactivity in Their Courses: Overcoming the Distance in Distance Education. Australian Journal of Teacher Education, 40(4). 
Karip, E. (2020). COVID19: Okullarin Kapatılması ve Sonrast, https://tedmem.org/vurus/covid-19-okullarinkapatilmasi-ve-sonrasi, Son erişim tarihi: 01 Mayss 2020.

Kaya, Z. (2002). Uzaktan eğitim. Ankara: PegemA Yayıncılık.

Kaysi, F. ve Aydemir, E. (2017). Uzaktan Eğitim Süreçlerindeki Etkileşim Boyutlarının Değerlendirilmesi. Sosyal Bilimler Dergisi, 4(11), 778-790.

OECD. (2020a). Education disrupted - education rebuilt: Some insights from PISA on the availability and use of digital tools for learning- OECD Education and Skills Today. https://oecdedutoday.com/coronaviruseducation-digital-tools-for-learning/

Özatay, F. ve Sak, G. (2020b). Covid19 Nedeniyle Sokağa Çıkma Yasă̆ı Uygulanırsa, TEPAV Politika Notu No, 202008.

Özatay, F. ve Sak, G. (2020a). Covid19'un Ekonomik Sonuçlarını Yönetebilmek İçin Ne Yapılabilir?, TEPAV Politika Notu No, 202006.

Öztürk, M. S., Yılmaz, N., Demir Erbil, D. ve Hazer, O. (2020). Covid19 pandemi döneminde hanehalkındaki çatışma ve birlik-beraberlik durumunun incelenmesi. Turkish Studies, 15(4), 295-314. https://dx.doi.org/10.7827/TurkishStudies.44424

Panchabakesan, S. (2011). Problems and prospectives in distance education in India in the 21st century. Problems of Education in The 21st Century, 30, 113-122.

PHA. (2020). COVID19 (Coronavirus). Public Health Agency, 18(2), 99-100. https://doi.org/10.1089/lrb.2020.29084.cov

Saavedra, J. (2020). Educational challenges and opportunities of the Coronavirus (COVID19) pandemic. https://blogs.worldbank.org/education/educational-challenges-and-opportunitiescovid-19-pandemic

Saran, S. (2020). Technology: Digital Epiphany? COVID19 and Our Tech Futures. In Insight Report Challenges and Opportunities in the Post-COVID19 World (24-27). Geneva: World Economic Forum. www.weforum.org.

Sarı, T., Nayır, F. (2020). Pandemi dönemi eğitim: sorunlar ve firsatlar. Turkish Studies, 15(4), 959-975. https://dx.doi.org/10.7827/TurkishStudies.44335

Shattuck, J., Dubins, B. ve Zilberman, D. (2011). International review of research in open and distance learning marylandonline's inter-institutional project to train higher education adjunct faculty to teach online. International Review of Research in Open and Distance Learning, 12(2), 40-61.

T.C. Sağlık Bakanlığı Halk Sağlığı Genel Müdürlüğü. (2020). Covid19 (SARS-CoV-2 Enfeksiyonu) Genel Bilgiler, Epidemioloji ve Tanı. Bilimsel Danışma Kurulu Çalışması. (Erişim Tarihi: 11.06.2020). https://covid19bilgi.saglik.gov.tr/depo/rehberler/Covid-19-rehberi/Covid

19 rehberı_genel bilgiler_epidemiyoloji_ve tanı.pdf.

Taylor, S. (2019). The Psychology of Pandemics: Preparing for the Next Global Outbreak of Infectious Disease. Cambridge Scholars Publishing.

Tuncer, M. ve Bahadır, F. (2017). Uzaktan Eğitim Programlarının Bu Programlarda Öğrenim Gören Öğrenci Görüşlerine Göre Değerlendirilmesi. Journal of Educational Reflections, 1(2), 29-38.

WHO. (2020). Past pandemics, http://www.euro.who.int/en/health-topics/communicable diseases/influenza/pandemic-influenza/past-pandemics

Yıldırım, A. ve Şimşek, H. (2011). Sosyal bilimlerde nitel araştırma yöntemleri. Ankara: Seçkin.

\section{Extended Abstract}

The Covid19 outbreak has revealed a social situation that the modern world has never experienced recently. This social situation upset the usual flow of life. A new social reality has emerged that you are not used to. This reality made many fields, including commerce, human relations, daily habits, transportation and education, unfeasible in their usual flow. Among these sectors, education was perhaps the most affected. Educational institutions suddenly closed and were helpless against the new situation. After this short-term helplessness, distance education was started almost all over the world, and sites, programs and portals that provide distance education have suddenly 
become the focus of education life. However, it was observed that administrators, teachers and students were not prepared enough for this process.

The Covid19 pandemic, which was effective all over the world in early 2020, is one of these crisis times. Due to the Covid19 pandemic, almost all over the world, educational institutions were closed in the spring semester of the 2019-2020 academic year and quarantine practices at various levels began. In this direction, schools at various levels all over the world have initiated the distance education process so that students do not miss their education. On this occasion, every educator and learner with or without distance education experience suddenly had to teach or take lessons with the distance education method. Educational institutions and educators have sought how to make courses with distance education and how to use various online tools. In this context, it can be stated that the world will no longer be the same in terms of distance education. Most of the trainers have never used distance education tools before.

Phenomenology design was used in this qualitative study. Phenomenological research focuses on phenomena that we are aware of but do not have an in-depth and detailed understanding and define the common meaning of several people's experiences with a phenomenon or concept.

The universe of the study consists of teachers working in public primary schools in the province of Şanliurfa. The study group was composed of 20 teachers who were determined based on an easily accessible sample. As a data collection tool, a semi-structured interview form consisting of open-ended questions developed by the researcher was used. For the data collection tool, firstly the literature was searched and the themes within the scope of the subject were tried to be found. Then, a question pool consisting of 17 questions was created to reveal these themes. The question pool was presented to an expert opinion consisting of 4 people, and as a result, it was decided that 9 questions clarified the subject and an interview form called "Opinions of Teachers Working in Primary Schools in Şanlıurfa Regarding Educational Activities Conducted During Covid19" was created.

When evaluated in general, it was found that the teachers, who were the participants of the study, adapted to the distance education process even though they had difficulties in the beginning. In addition, it is understood that the participant group Ministry of National Education conducts the process correctly despite its shortcomings, students have difficulties in terms of equipment and access in terms of information tools, teachers are in favor of face-toface education despite everything and do not equate face-to-face education with distance education.

As a result, although the situation in the context of crisis management is considered successful, it is understood that there is no complete opportunity for distance education, so it is important to establish a distance education department within the Ministry of National Education. It is also necessary to provide in-service trainings for teachers on distance education, and to provide equipment support to teachers and students to ensure that the distance education process runs correctly and completely. It may be suggested to diversify and make educational materials more effective, strengthen the internet infrastructure, especially in rural areas such as villages, involve families in the management of distance education, and support distance education activities with home visits, albeit limited. 